\title{
Antibacterial effect of chitosan from squid pens against Porphyromonas gingivalis bacteria
}

\author{
Latief Mooduto, Dian Agustin Wahjuningrum*, Agatha Prita A, Cecilia G. J. Lunardhi \\ Department of Conservative Dentistry, Faculty of Dental Medicine, Universitas Airlangga, \\ Surabaya, Indonesia
}

Received: September 2018, Accepted: February 2019

\begin{abstract}
Background and Objectives: Chitosan, a polysaccharide derived from squid pens - the squid waste, is gaining considerable interests in biomedical engineering due to the biodegradability, biocompatibility, nontoxicity, and antibacterial activity. It is necessary to eradicate the bacteria from root canal in endodontic treatment, including Porphyromonas gingivalis. P. gingivalis is one of the most prevalently found bacteria in root canals and its presence can cause endodontic treatment failure. This study was conducted to find the antibacterial effect of chitosan from squid pen against $P$. gingivalis at a certain concentration. Materials and Methods: Chitosan $1.5 \%$ (w/v) was diluted in several tubes. The lowest concentration with no bacterial growth was considered to have antibacterial activity against $P$. gingivalis.

Results: There was no bacterial growth in nutrient agar media at the concentration of $10.75 \%$.

Conclusion: Chitosan that was made from squid pens has antibacterial activity against $P$. gingivalis.
\end{abstract}

Keywords: Chitosan; Squid pen; Antibacterial effect; Porphyromonas gingivalis

\section{INTRODUCTION}

Chitosan is a polysaccharide derived from chitin through deacetylation process (1). It is widely developed for various biomedical purposes such as tissue engineering, bone, nerves, skin, wound-healing, and burn wound treatment (2). The antibacterial ac-

"Corresponding author: Dian Agustin Wahjuningrum, $\mathrm{PhD}$, Department of Conservative Dentistry, Faculty of Dental Medicine, Universitas Airlangga, Surabaya, Indonesia.

Tel: +62315030255

Fax: +62315020256

Email: dian-agustin-w@fkg.unair.ac.id tivity of chitosan is considered to be able to affect wide-spectrum of bacteria (1).

In this study, the chitosan antibacterial test was performed against Porphyromonas gingivalis. $P$. gingivalis is an anaerobic Gram-negative bacteria with its cell membrane mainly composed of lipopolysaccharides (3). This bacteria is one of the dominant pathogenic bacteria involved in endodontic-perio lesions $(4,5)$.

\section{MATERIALS AND METHODS}

Chitosan production. Chitosan production from squid pen was done in laboratory according to 
Chaussard and Domard method in Goy et al. (1). Squid pen with an average length of $30.4 \mathrm{~cm}$ in total of 10.7 grams that had been taken from the dorsal part of squid was dried using an oven at $50^{\circ} \mathrm{C}$ for 8 hours. Squid pen that has been dried was ground with a grinder to produce squid pen powder in size of 60 mesh. Shortly, the squid powder was then mixed with $10 \% \mathrm{NaOH}$ and heated at $60^{\circ} \mathrm{C}$ with constant stirring at the rotary shaker at $125 \mathrm{rpm}$ for 24 hours for deproteinization and then added into vacuum filtration to remove residual water. The obtained dried squid pen powder was washed to neutralizeits $\mathrm{pH}$ $(\mathrm{pH}=7)$ then lyophilized using freeze drier into a powder called chitosan. In this study, we managed to obtain 1.765 gr of chitosan.

Chitosan suspension was prepared by mixing 1.5 gram of chitosan powder with $100 \mathrm{ml}$ of $1 \%$ acetic acid to get $1.5 \%$ (w/v) chitosan suspension.

Antibacterial activity test. The antibacterial test of chitosan from squid pen was carried by dilution method. Based on previous research, it was found that concentrations with antibacterial activity potency were between $12.5 \%$ and $6.25 \%$. In this study, 10 $\mathrm{ml}$ chitosan suspension was used for the concentration of $12.5 \%$ and then diluted four times to a concentration of $6.25 \%$ in 5 test tubes. Aliquot of 0.1 $\mathrm{ml}$ standardized suspension of $P$. gingivalis bacteria with $0.5 \mathrm{McFarland}\left(1.5 \times 10^{8} \mathrm{CFU} / \mathrm{ml}\right)$ was added to the test tube. Each tube was incubated in anaerobic condition in the incubator for $2 \times 24$ hours at $37^{\circ} \mathrm{C}$. After that, the culture was spread into the nutrient media and incubated again for 24 hours to allow bacterial growth in order to do the calculation of colonies. If the number of colonies in the culture medium is less than $0.1 \%$ of the positive control, it means the material has antibacterial activity (6).

\section{RESULTS}

The result of colony counting on each concentration is shown in Tabel 1. From the result shown in Table 1 , the ability of chitosan in bacterial inhibition was increased as the concentration increase, it can be seen from the decrease of bacterial colony number.

Based on the calculation of the colony number, it was found that bacterial growth at concentrations of $12.5 \%$ and $10.75 \%$ was $0 \%$ compared to positive control colonies or it can be concluded there was no bacterial growth. At the concentrationof $9.25 \%$, there are $3.16 \%$ bacterial colonies' growth compared to positive control colonies. At the concentration of $7.75 \%$, there are $5.98 \%$ bacterial colonies' growth compared to positive control colonies, and at the concentrationof $6.25 \%$, there are $10.13 \%$ bacterial colonies' growth compared to positive control colonies (Fig. 1).

\section{DISCUSSION}

This experimental study aimed to find the anti-

Table 1. Results of colony counting in dilution method to test antibacterial activity against Porphyromonas gingivalis

\begin{tabular}{llll}
\hline & N & $\begin{array}{l}\text { Colonies mean } \\
\text { (CFU) }\end{array}$ & \\
\hline Positive control & 4 & 149.5 & $100 \%$ \\
Concentration of 12.5\% & 4 & 0 & $0 \%$ \\
Concentration of 10.75\% & 4 & 0 & $0 \%$ \\
Concentration of 9.25\% & 4 & 4,75 & $3,16 \%$ \\
Concentration of 7.75\% & 4 & 9 & $5,98 \%$ \\
Concentration of 6.25\% & 4 & 15,25 & $10,13 \%$ \\
\hline
\end{tabular}

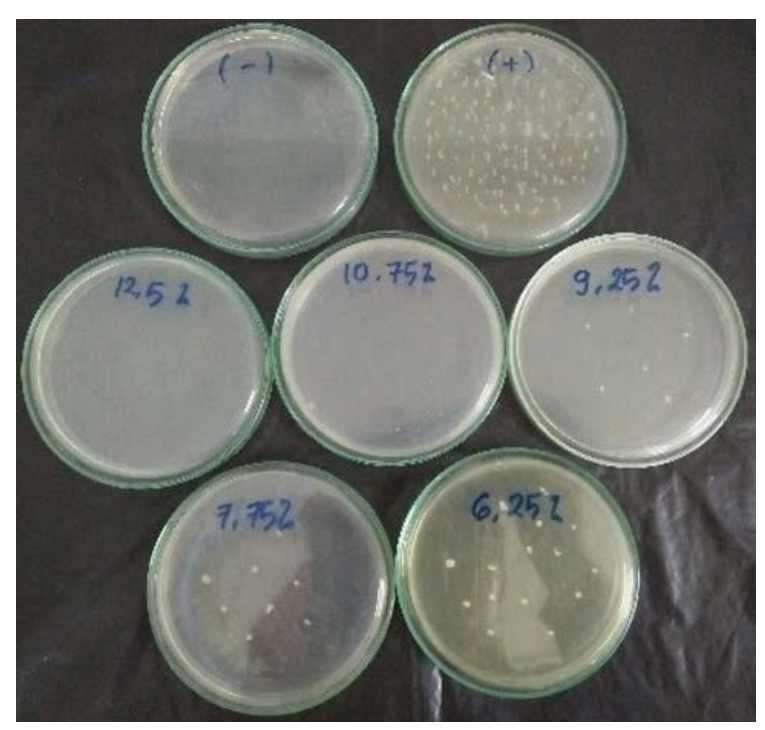

Fig. 1. Cultivation of bacterial suspension in nutrient agar media for negative control (-), positive control (+), concentration of $12,5 \%$, concentration of $10,75 \%$, concentration of $9,25 \%$, concentration of $7,75 \%$, and concentration of $6,25 \%$, to allow colony counting. 
bacterial effect of chitosan from squid pen against $P$. gingivalis. $P$. gingivalis is known to be one of the etiological agents and key pathogens in the initiation of combined perio-endo lesions (7). $P$. gingivalis may survive in the host under anaerobic conditions as it may avoid host defense mechanisms by migrating across the basal membrane of the epithelial layer to invade connective tissue $(5,8)$.

The material used in this study is chitosan from squid pen which was suspected to have antibacterial effect against $P$. gingivalis. Based on previous research, it was found that concentrations with antibacterial potency were between $12.5 \%$ and $6.25 \%$. Therefore, in this study, the concentration used was reduced to $12.5 \%, 10.75 \%, 9.25 \%, 7.75 \%$ and $6.25 \%$. Chitosan used in this study is $1.5 \%(\mathrm{w} / \mathrm{v})$. The solvent used to solve chitosan was $1 \%$ acetic acid because it effectively increases the inhibition effect of chitosan against bacterial growth (9).

The results of antibacterial test by the dilution method showed that the concentration of $10.75 \%$ was the minimum inhibition concentration (MIC). At the concentration of $9.25 \%$, there were $3.16 \%$ bacterial colony growth compared to positive control colonies. At the concentration of $7.75 \%$, there were $5.98 \%$ bacterial colony growth compared to positive control colonies, and at the concentration of $6.25 \%$, there were $10.13 \%$ bacterial colony growth compared to positive control colonies.

From the results obtained, we found that chitosan from squid pen has antibacterial effect against $P$. gingivalis. Chitosan from squid pen is able to inhibit bacterial growth (bacteriostatic) and kill bacteria (bactericidal). The mechanism of inhibition of bacterial growth by chitosan is complicated and involves several factors. To date, there are three models proposed in connection with the mechanism of chitosan in inhibiting bacterial growth and killing bacteria. First, chitosan is able to inhibit the growth of $P$. gingivalis because chitosan has cationic properties (3). The cationic properties of chitosan are due to the amines, R-N (CH3)3+, so that chitosan interacts with the bacterial cell membrane which is negative. Strong electrostatic interaction between chitosan and bacterial cell membrane causes a change in the permeability of the bacterial membrane. As the permeability of the bacterial membrane alters, the transfer of material through the cell membrane is disrupted resulting in an osmotic pressure imbalance that triggers bacterial lysis. Because bacteria lysis, protein fluids and other intracellular materials will come out of the bacteria resulting in death $(10,11)$.

Second, chitosan can penetrate into the nucleus of bacterial cells and bind to bacterial DNA thus inhibiting the synthesis of mRNA and protein (9). Chitosan that binds to bacterial DNA can also interfere with the cell metabolic energy processes resulting in bacterial death (12). Third, chitosan works inhibiting and killing bacteria due to the metal chelating process. Chitosan molecules that surround the bacteria can form complexes with existing metals and inhibit the flow of important nutrients for bacteria (1).

From the three mechanisms proposed above, the electrostatic interactions that occur between chitosan and the outer membrane of bacteria are the most likely mechanisms to occur. According to Rafaat et al. (2018), chitosan has more effect on the outer membrane of bacteria because for the chitosan to penetrate up to the cell nucleus there are several layers of bacteriathat must be penetrated and it requires certain particle size of chitosan (12).

In conclusion, Chitosan from squid pen has antibacterial activity against $P$. gingivalis bacteria at concentration of $10.75 \%$.

\section{REFERENCES}

1. Goy RJ, Morais STB, Assis OBG. Evaluation of the antimicrobial activity of chitosan and its quaternized derivative on $E$. coli and $S$. aureus growth. Rev Bras Farmacogn 2016;26:122-127.

2. Wray LS, Kaplan DL (2014). Biomaterials for Scaffolds: Natural Polymers'. In: Scaffolds for Tissue Engineering: Biological Design, Materials, and Fabrication. Ed, Pan Stanford Publishing, 1st ed. Singapore, Singapore, p. 316.

3. Diaz L, Hoare A, Soto C, Bugueno I, Silva N, Dutzan $\mathrm{N}$, et al. Changes in lipopolysaccharide profile of Porphyromonas gingivalis clinical isolates correlate with changes in colony morphology and polymyxin B resistance. Anaerobe 2015; 33:25-32.

4. Bostanci N, Belibasakis GN. Porphyromonas gingivalis: an invasive and evasive opportunistic oral pathogen. FEMS Microbiol Lett 2012; 333: 1-9.

5. Gomes BP, Berber VB, Kokaras AS, Chen T, Paster BJ. Microbiomes of endodontic-periodontal lesions before and after chemomechanical preparation. J Endod 2015; 41:1975-1984.

6. Mahon, CR, Lehman, DC, Manuselis, G (2015). Text- 


\section{LATIEF MOODUTO ET AL.}

book of Diagnostic Microbiology. 5th ed. Elsevier Inc. China.

7. Mysak J, Podzimek S, Sommerova P, Lyuya-Mi Y, Bartova J, Janatova T, et al. Porphyromonas gingivalis: major periodontopathic pathogen overview. J Immunol Res 2014; 2014:476068.

8. Newman MG, Takei HH, Klokkevold PR, Carranza FA (2015). Periodontal Pathogenesis. In: Carranza's Clinical Periodontology. Saunders, 12th ed. Canada, p. 91.

9. Kim KM, Son JH, Kim SK, Weller CL, Hanna MA. Properties of chitosan films as a function of $\mathrm{pH}$ and sol- vent type. J Food Sci 2006; 71(3):E119-E124.

10. Kara F, Aksoy EA, Yuksekdag Z, Hasirci N, Aksoy S. Synthesis and surface modification of polyurethanes with chitosan for antibacterial properties. Carbohydr Polym 2014; 112: 39-47.

11. Li J, Wu Y, Zhao L. Antibacterial activity and mechanism of chitosan with ultra high molecular weight. Carbohydr Polym 2016; 148:200-205.

12. Raafat D, Von Bargen K, Haas A, Sahl H. Insights into the mode of action of chitosan as an antibacterial compound. Appl Environ Microbiol 2008; 74:37643773 . 